\title{
Effect of Brevibacterium iodinum RS16 and Methylobacterium oryzae CBMB20 Inoculation on Seed Germination and Early Growth of Maize and Sorghum-sudangrass hybrid Seedling under Different Salinity Levels
}

\author{
Kiyoon Kim, Seongwoong Hwang ${ }^{1}$, Venkatakrishnan Sivaraj Saravanan ${ }^{2}$, and Tongmin Sa* \\ Department of Environmental and Biological Chemistry, Chungbuk National University, Cheongju, 361-763, Korea \\ ${ }^{I}$ Division of Reclaimed Land Agriculture Research, National Institute of Crop Science, Iksan, 570-080, Korea \\ ${ }^{2}$ Department of Microbiology, Indira Gandhi College of Arts and Science, Puducherry, 605-007, India
}

\begin{abstract}
Salinity is one of the most relevant abiotic factor limiting crop yield and its net primary productivity. In addition, salinity induces an increased stress ethylene synthesis in plants which, in tum, exacerbate the responses to the stressor. Bacterial single or co-inoculation effect was tested using previously characterized plant growth promoting (PGP) bacteria Brevibacterium iodinum RS16 and Methylobacterium oryzae CBMB20 on maize and sorghum-sudan grass hybrid under different concentrations of $\mathrm{NaCl}$. Non-inoculated maize and sorghum-sudangrass hybrid showed $33.4 \%$ and $20.0 \%$ reduction in seed germination under highest $\mathrm{NaCl}(150 \mathrm{mM})$ level tested. However, under the same $\mathrm{NaCl}$ concentration, co-inoculation with $B$. iodinum RS16 and $M$. oryzae CBMB20 PGP strains increased the seed germination in maize (16.7\%) and sorghumsudangrass hybrid (4.4\%). In Gnotobiotic growth pouch experiments conducted for maize and sorghumsudangrass hybrid, co-inoculation of PGP B. iodinum RS16 and M. oryzae CBMB20 mitigated the salinity stress and promoted root length by $22.9 \%$ and $29.7 \%$, respectively. Thus the results of this study could help in development of potential bioinoculants that may be suitable for crop production under saline conditions.
\end{abstract}

Key words: Salinity stress, NaCl, Brevibacterium iodinum RS16, Methylobacterium oryzae CBMB20, maize, Sorghum-sudangrass hybrid.

\section{Introduction}

Salinity is one of major abiotic stress in arid and semi-arid regions, more than half of the irrigated arable land area of the world are affected with salts, thus it substantially reduce crop yield by more than $50 \%$ (Bray et al. 2000). It is one of the most important factor limiting crop production, especially in sensitive crops (Zadeh and Naeini, 2007). Saline soils contain sufficient soluble salts to suppress plant growth through a series of interacting factors such as osmotic potential effect, ion toxicity and antagonism; they in turn induce nutrient imbalances (Neumann, 1995). Salinity stress affects all stages of crop growth, especially, seed germination and seedling growth stages are more sensitive for most plant species (Cuartero et al. 2006). Seedling growth of

\footnotetext{
Received : January 6. 2012 Accepted : January 27. 2012

*Corresponding author : Phone: +82432612561

E-mail: tomsa@chungbuk.ac.kr
}

plant is the most critical stage in plant development and is highly responsive to the environmental conditions (Saritha et al. 2007). The effects of salinity on germination could be related to the imbalance in endogenous levels of growth hormones (Zholkevich and Pustovoytova, 1993; Jackson, 1997). Therefore, seeds with rapid germinating ability under salinity stress may be expected to achieve seedling establishment and more salinity tolerance and hence higher yields (Munns, 2002; Bybordi and Tabatabaei, 2009).

Plant growth promoting rhizobacteria (PGPR) are a group of bacteria that actively colonize the rhizosphere soil or in phyllosphere region and it helps in enhancement of plant growth and yield (Vessey, 2003). The mechanisms of plant growth promotion includes phytohormone production (Egamberdiyeva, 2007; Shaharoona et al. 2006), asymbiotic $\mathrm{N}_{2}$ fixation (Salantur et al. 2006), production of siderophores, synthesis of antibiotics, enzymes and/or fungicidal compounds (Bharathi et al. 2004 and Jeun et al. 2004; Ahmad et al. 2007) and 
solubilization of mineral nutrients (Cattelan et al. 1999). Under salinity stress, PGPR have positive effects on plants specifically on germination rate and seedling growth (Kokelis-Burelle et al. 2006). Importantly the PGPR containing 1-aminocyclopropane-1-carboxylic acid (ACC) deaminase were considered to effectively facilitate the early growth of plants, especially under stressful conditions such as flooding, heavy metals, phytopathogens, drought and high salinity (Grichko et al. 2001; Belimov et al. 2005; Mayak et al. 2004). Ethylene is an important phytohormone connected with fruit ripening, however, overproduction of ethylene under stressful conditions can result in the inhibition of plant growth or death, especially for seedlings (Glick et al. 1997 and Ghosh et al. 2003). PGPR containing ACC deaminase can hydrolyze ACC, the immediate precursor of ethylene, to a-ketobutyrate and ammonia, leading to reduction in ethylene levels, thus promoting plant growth (Glick et al. 1998). In general, ethylene production, ACC concentration, ACC synthase (ACS), and ACC oxidase (ACO) enzyme activities increase with increasing levels of salinity stress. Inoculation with ACC deaminase producing PGPR reduced ethylene production, ACC concentration, ACS and ACO activities in salinity stress (Siddikee et al. 2011a). ACC deaminase- producing PGPR may assist plant growth by alleviating deleterious effects of stress ethylene. Moreover, PGPR are found to tolerate high salinity levels, which are often detrimental to growth of important crop plants (Bacilio et al. 2004).

The objective of this work was to examine in the effect of ACC deaminase producing PGP strains inoculation on seed germination and early growth of maize (Zea mays L.) and sorghum-sudangrass (Sorghum bicolor L.) hybrid under different salinity levels.

\section{Materials and Methods}

\section{Bacterial strains and culture inoculum preparation} The halotolerant Brevibacterium iodinum RS16 was isolated from coastal saline soil of the Yellow sea, Incheon, South Korea. It possesses plant growth promoting (PGP) traits like nitrogen fixation and ACC deaminsae actvity (Siddikee et al. 2011b). The culture was maintained in Tryptic soy agar (TSA) medium supplemented with $5 \%(\sim 0.85 \mathrm{M}) \mathrm{NaCl}(\mathrm{pH} 7.2)$. For experimental studies $1.0 \mathrm{~mL}$ of the initially mass multiplied culture $\left(1 \times 10^{8} \mathrm{cfu} \mathrm{mL}^{-1}\right)$ was transferred to $100 \mathrm{~mL}$ fresh TSB supplemented with $5 \%(0.85 \mathrm{M}) \mathrm{NaCl}$ and allowed to grow for $24 \mathrm{~h}$. The other bacteria used in this study was pink-pigmented facultative methylotroph (PPFM) Methylobacterium oryzae strain CBMB20, which was isolated from stem tissues of rice and well characterized in related to PGP activities (Madhaiyan et al. 2007). The culture was maintained in ammonium mineral salt (AMS) media with $0.5 \%$ sodium succinate supplemented at $\mathrm{pH}$ 7.2. For experimental studies, $1.0 \mathrm{~mL}$ initially mass multiplied culture $\left(1 \times 10^{8} \mathrm{cfu} \mathrm{mL}^{-1}\right)$ was transferred to $100 \mathrm{~mL}$ fresh AMS broth and allowed to grow for $72 \mathrm{~h}$.

Effect of $\mathrm{NaCl}$ concentration on maize and sorghumsudangrass hybrid seed germination Maize seeds were surface sterilized by immersion in $70 \%$ ethanol for $1 \mathrm{~min}$ and $6 \% \mathrm{NaOCl}$ for $5 \mathrm{~min}$, followed by thorough rinsing with sterile distilled water (7-10 times). Sorghum-sudangrass hybrid seeds were surface sterilized by immersion in $70 \%$ ethanol for $2 \mathrm{~min}$ and $1 \% \mathrm{NaOCl}$ for $3 \mathrm{~min}$, followed by thorough rinsing in sterile distilled water (7-10 times). For conducting germination test, ten seeds were maintained per treatment on sterilized filter paper (Whatman No. 2) soaked in a $5 \mathrm{~mL}$ solution of $0,50,100$ and $150 \mathrm{mM} \mathrm{NaCl}$ in Petri dishes. Treatment without $\mathrm{NaCl}$ addition was considered as control and each $\mathrm{NaCl}$ concentration was assigned as separate treatment, the experiment was conducted in triplicate. Germination potential was observed till 3 days at $28 \pm 11^{\circ} \mathrm{C}$ under dark condition in a plant growth chamber (DS 54 GLP, DASOL Scientific Co., Ltd., Republic Korea). The number of germinated seeds was recorded every $24 \mathrm{~h}$.

Bacterial inoculation effects on maize and sorghumsudangrass hybrid seed germination under salinity stress Germination potential of the seeds under different $\mathrm{NaCl}(50,100$ and $150 \mathrm{mM})$ concentrations was tested in presence of single inoculant or under co-inoculated condition. Surface sterilized maize and sorghum-sudangrass hybrid seeds were soaked in bacterial suspension $\left(1 \times 10^{8} \mathrm{cfu} \mathrm{mL}^{-1}\right)$ of each bacteria and imbibed for $4 \mathrm{~h}$. Single inoculation treatments received $20 \mathrm{~mL}$ of culture as inoculum, and in case of co-inoculation, $10 \mathrm{~mL}$ of each culture were used. In case of control no seed bacterization was carried out. The rate of germination was estimated using a modified 
Timson index of germination velocity: germination velocity $=\sum \mathrm{G} / \mathrm{t}$, where $\mathrm{G}$ is the percentage of seed germination at $24 \mathrm{~h}$ intervals and $\mathrm{t}$ is the total germination period (Khan and Ungar, 1985).

\footnotetext{
Assessment of bacterial inoculation effects on maize and sorghum-sudangrass hybrid seedling using gnotobiotic growth pouch assay under salinity stress Surface sterilized seeds of maize and sorghum-sudangrass hybrid were imbibed in B. iodinum RS16 and M. oryzae CBMB20 cell suspensions for $4 \mathrm{~h}$. Salinity levels were maintained at 50,100 and $150 \mathrm{mM}$ of $\mathrm{NaCl}$ and bacterial treatments included either single or dual inoculation of cultures. Three sprouted seeds of maize and five seeds of sorghum-sudangrass hybrid were aseptically transferred to growth pouches (CYG seed germination pouch, Mega International Manufacturer, USA) which were filled with $20 \mathrm{~mL}$ of 50,100 and $150 \mathrm{mM} \mathrm{NaCl}$ solution. The pouches were incubated in the growth chamber at $28 \pm 1{ }^{\circ} \mathrm{C}$, a relative humidity of $70 \%$ and a dark/light cycle beginning with $12 \mathrm{~h}$ of dark followed by $12 \mathrm{~h}$ of light. After 3 days of incubation, $2 \mathrm{~mL}$ water containing 50, 100 and $150 \mathrm{mM}$ $\mathrm{NaCl}$ (for salinity stress imposed treatments) were added to the pouches. The length of primary roots formed after 7 days was measured.
}

Statistical analysis All data were subjected to analysis of variance (ANOVA). Significance at 5\% level was tested by Least Significant Difference (LSD) using SAS package, Version 9.1 (SAS, 2009).

\section{Results and Discussion}

Effect of salinity stress on maize and sorghumsudangrass hybrid seed germination Salinity stress slowed down water uptake by seeds, thereby inhibiting their germination and root elongation (Uhvits, 1946; Simon, 1984; Werner and Finkelstein, 1995). Salinity affects seed germination due to osmotic inhibition of water availability, toxic effects and nutritional imbalance caused due to salt ions. In the life cycle of plant germination, seedling and flowering stages are more critical for salinity stress. Maize and sorghum-sudangrass hybrid seeds in the control dishes $(0 \mathrm{mM} \mathrm{NaCl})$ had the highest germination percentage (96.7\%) after $72 \mathrm{~h}$ of incubation. However, germination percentage decreased as $\mathrm{NaCl}$ concentration increased (Table 1 and Table 2). Significant reduction on seed germination was observed with all the three levels of salinity (50, 100 and 150 $\mathrm{mM}$ ) stress imposed on the maize and sorghumsudangrass hybrid. At $50 \mathrm{mM} \mathrm{NaCl}$ concentration, germination of maize seeds were reduced by $6.7 \%$,

Table 1. Germination percentage of maize seeds under different levels of salinity stress.

\begin{tabular}{lccc}
\hline \hline \multirow{2}{*}{ Treatment } & \multicolumn{3}{c}{ Germination percentage (\%) } \\
\cline { 2 - 4 } & $24 \mathrm{~h}$ & $48 \mathrm{~h}$ & $72 \mathrm{~h}$ \\
\hline Control & $6.7 \pm 3.3 \mathrm{a}$ & $86.7 \pm 3.3 \mathrm{a}$ & $96.7 \pm 3.3 \mathrm{a}$ \\
$50 \mathrm{mM} \mathrm{NaCl}$ & $3.3 \pm 3.3 \mathrm{a}$ & $50.0 \pm 5.7 \mathrm{~b}$ & $90.0 \pm 5.8 \mathrm{a}$ \\
$100 \mathrm{mM} \mathrm{NaCl}$ & $3.3 \pm 3.3 \mathrm{a}$ & $36.7 \pm 3.3 \mathrm{c}$ & $83.3 \pm 3.3 \mathrm{ab}$ \\
$150 \mathrm{mM} \mathrm{NaCl}$ & $3.3 \pm 3.3 \mathrm{a}$ & $26.7 \pm 6.6 \mathrm{c}$ & $63.3 \pm 3.3 \mathrm{~b}$ \\
\hline
\end{tabular}

Each value represents the average of three replicates per treatment \pm SE (standard Error). In the same column, significant differences according to LSD at $P \leq 0.05$ levels are indicated by different letters.

Table 2. Germination percentage of sorghum-sudangrass hybrid seeds under different levels of salinity stress.

\begin{tabular}{lccc}
\hline \hline \multirow{2}{*}{ Treatment } & \multicolumn{3}{c}{ Germination percentage (\%) } \\
\cline { 2 - 4 } & $24 \mathrm{~h}$ & $48 \mathrm{~h}$ & $72 \mathrm{~h}$ \\
\hline Control & $93.3 \pm 6.7 \mathrm{a}$ & $93.3 \pm 6.7 \mathrm{a}$ & $96.7 \pm 3.3 \mathrm{a}$ \\
$50 \mathrm{mM} \mathrm{NaCl}$ & $50.0 \pm 5.8 \mathrm{~b}$ & $80.0 \pm 5.8 \mathrm{ab}$ & $86.7 \pm 3.3 \mathrm{ab}$ \\
$100 \mathrm{mM} \mathrm{NaCl}$ & $40.0 \pm 5.8 \mathrm{bc}$ & $70.0 \pm 5.8 \mathrm{~b}$ & $86.7 \pm 6.7 \mathrm{ab}$ \\
$150 \mathrm{mM} \mathrm{NaCl}$ & $23.3 \pm 6.7 \mathrm{c}$ & $70.0 \pm 5.8 \mathrm{~b}$ & $76.7 \pm 6.7 \mathrm{~b}$ \\
\hline
\end{tabular}

Each value represents the average of three replicates per treatment \pm SE (standard Error). In the same column, significant differences according to LSD at $P \leq 0.05$ levels are indicated by different letters. 
However, severe reduction (33.4\%) was observed at $150 \mathrm{mM} \mathrm{NaCl}$ (Table 1). For sorghum-sudangrass hybrid, germination was reduced by $10.0 \%$ at $50 \mathrm{mM}$ $\mathrm{NaCl}$ and $20.0 \%$ reduction at $150 \mathrm{mM} \mathrm{NaCl}$ concentration tested (Table 2). The germination percentages of maize and sorghum-sudangrass hybrid germination was severely reduced $(>50 \%)$ at $150 \mathrm{mM} \mathrm{NaCl}$. Several earlier studies also documented the relationship between salt stress and reduction in seed germination (Gill et al. 2002; Almodares et al. 2007; Blanco et al. 2007).

Effect of inoculation of PGP strains on gemination of maize and sorghum-sudangrass hybrid seed under salinity stress Inoculation of $B$. iodinum RS16 and M. oryzae CBMB20 and their co-inoculation increased germination of maize seeds compared to non-inoculated control by $16.7 \%$ at $150 \mathrm{mM} \mathrm{NaCl}$ (Table 3). M. oryzae CBMB20 and co-inoculation increased germination of sorghum-sudangrass hybrid seeds compared to noninoculated control by $4.4 \%$ at $150 \mathrm{mM} \mathrm{NaCl}$ (Table 4). In general, rate of maize and sorghum-sudangrass hybrid seeds germination decreased with increasing levels of salinity. However, B. iodinum RS16 or M. oryzae $\mathrm{CBMB} 20$ alone and their co-inoculation treatments showed increased rate of maize and sorghum-sudangrass hybrid seeds germination compared to non-inoculated control at different levels of salinity stress (Figure 1). In an earlier study under in vitro condition, seed treatment with PGPR strains improved seed germination, seedling vigor, seedling emergence and seedling stand over the control (Egamberdieva, 2009). In particular, lettuce seed germination was enhanced under salt stress with the help of Azospirillum inoculation, it further improved the fresh and dry weights accumulation and biomass partition to the aerial portions of the plant (Barassi et al. 2006).

Table 3. Effect of B. iodinum RS16, M. oryzae CBMB20 inoculation on germination of maize seeds under different levels of salinity stress.

\begin{tabular}{lccc}
\hline \hline \multirow{2}{*}{ Treatment } & \multicolumn{3}{c}{ Germination percentage (\%) } \\
\cline { 2 - 3 } & $50 \mathrm{mM} \mathrm{NaCl}$ & $100 \mathrm{mM} \mathrm{NaCl}$ & $150 \mathrm{mM} \mathrm{NaCl}$ \\
\hline Non-inoculation & $90.0 \pm 5.8 \mathrm{a}$ & $83.3 \pm 3.3 \mathrm{a}$ & $63.3 \pm 3.6 \mathrm{~b}$ \\
B. iodinum RS16 & $93.3 \pm 3.3 \mathrm{a}$ & $86.7 \pm 3.3 \mathrm{a}$ & $80.0 \pm 5.8 \mathrm{a}$ \\
M. oryzae CBMB20 & $90.0 \pm 5.8 \mathrm{a}$ & $93.3 \pm 3.3 \mathrm{a}$ & $80.0 \pm 5.8 \mathrm{a}$ \\
Co-inoculation & $96.7 \pm 3.3 \mathrm{a}$ & $93.3 \pm 3.3 \mathrm{a}$ & $80.0 \pm 5.8 \mathrm{a}$ \\
\hline
\end{tabular}

Each value represents the average of three replicates per treatment \pm SE (standard Error). In the same column, significant differences according to LSD at $P \leq 0.05$ levels are indicated by different letters. The germination percentage were measured on 96 hour after sowing.
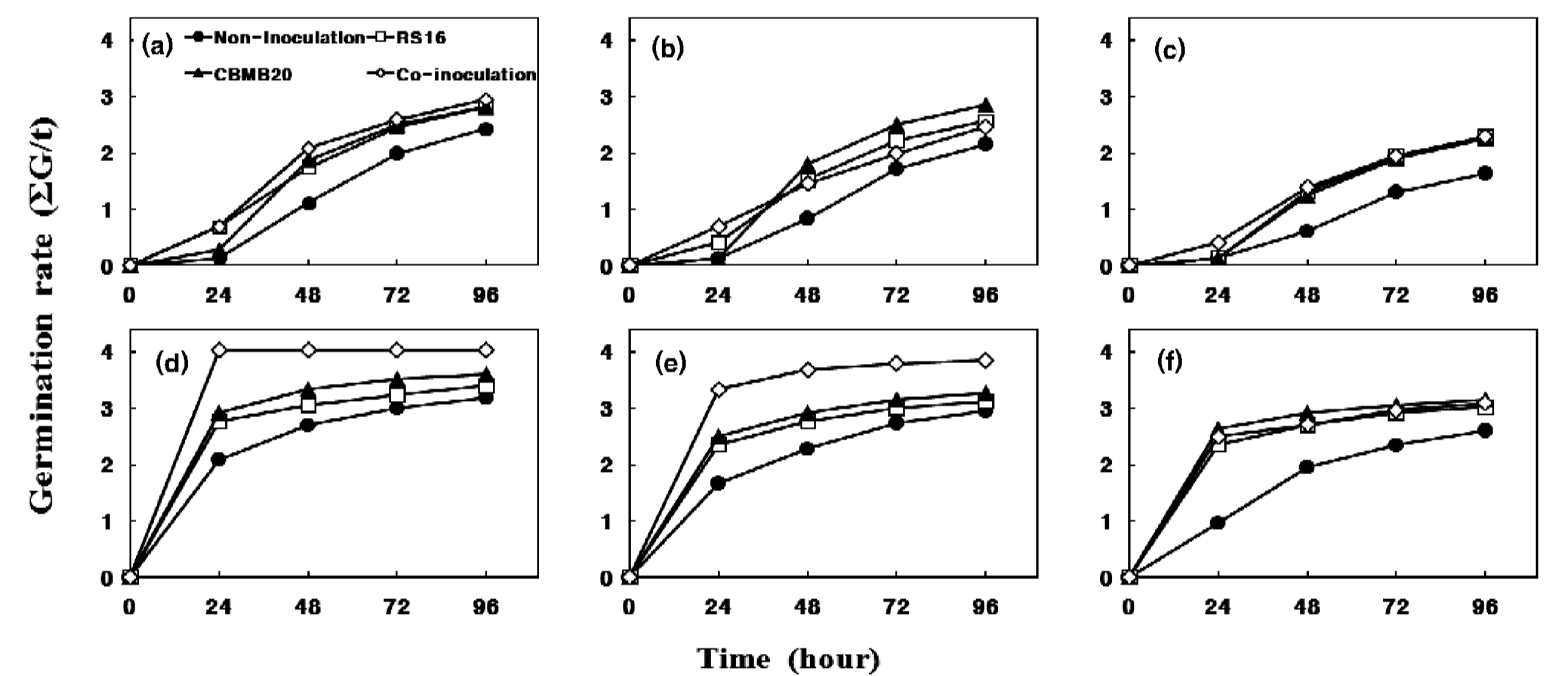

Fig. 1. Effect of B. iodinum RS16 and M. oryzae CBMB20 inoculation on gemination rate ( $\left.\sum \mathrm{G} / \mathrm{t}\right)$ of maize and sorghumsudangrass hybrid under different levels of salinity stress (a; maize $+50 \mathrm{mM} \mathrm{NaCl}$, b; maize $+100 \mathrm{mM} \mathrm{NaCl}$, c; maize + $150 \mathrm{mM} \mathrm{NaCl}$, d; sorghum $+50 \mathrm{mM}$, e; sorghum + $100 \mathrm{mM}$, f; sorghum $+150 \mathrm{mM}$ ). In absence of $\mathrm{NaCl}$ and bacterial inoculation on maize and sorghum-sudangrass hybrid germination rate $\left(\sum \mathrm{G} / \mathrm{t}\right)$ was 2.98 and 3.95 , respectively at $96 \mathrm{~h}$. 
Effect of salinity stress on maize and sorghumsudangrass hybrid seedling growth in gnotobiotic growth pouch assay Growth of maize and sorghumsudangrass hybrid seedlings exposed to salinity stress for 7 days were significantly affected compared to seedlings grown in the absence of $\mathrm{NaCl}$ and bacterial inoculation (statistical results not included). Similar results were found in the study by Mohammad et al. (1998) where both root length and root surface area per plant decreased significantly under higher salinity conditions. $\mathrm{NaCl}$ level at $150 \mathrm{mM}$ decreased root length in both maize and sorghum-sudangrass hybrid compared to seedlings grown in the absence of $\mathrm{NaCl}$ and bacterial inoculation (Table 5 and Table 6). Root length of maize was $13.4 \%$ and $62.7 \%$ lower at $50 \mathrm{mM}$ and $150 \mathrm{mM}$ $\mathrm{NaCl}$ treatments respectively, when compared to seedlings grown in the absence of $\mathrm{NaCl}$ and bacterial inoculation $(21.7 \mathrm{~cm})$. Root length of sorghum-sudangrass hybrid seedling was $16 \%$ and $55.4 \%$ lower at $50 \mathrm{mM}$ and $150 \mathrm{mM} \mathrm{NaCl}$ treatments compared to seedlings without

Table 4. Effect of $B$. iodinum RS16, M. oryzae CBMB20 inoculation on germination of sorghum-sudangrass hybrid seeds under different levels of salinity stress.

\begin{tabular}{lccc}
\hline \hline \multirow{2}{*}{ Treatment } & \multicolumn{3}{c}{ Germination percentage (\%) } \\
\cline { 2 - 4 } & $50 \mathrm{mM} \mathrm{NaCl}$ & $100 \mathrm{mM} \mathrm{NaCl}$ & $150 \mathrm{mM} \mathrm{NaCl}$ \\
\hline Non-inoculation & $90.0 \pm 5.7 \mathrm{a}$ & $86.7 \pm 6.7 \mathrm{a}$ & $80.0 \pm 5.8 \mathrm{a}$ \\
B. iodinum RS16 & $93.3 \pm 6.8 \mathrm{a}$ & $83.3 \pm 3.3 \mathrm{a}$ & $80.0 \pm 5.8 \mathrm{a}$ \\
M. oryzae CBMB20 & $93.3 \pm 3.3 \mathrm{a}$ & $86.7 \pm 3.3 \mathrm{a}$ & $83.3 \pm 6.7 \mathrm{a}$ \\
Co-inoculation & $96.7 \pm 3.3 \mathrm{a}$ & $96.7 \pm 3.3 \mathrm{a}$ & $83.3 \pm 6.7 \mathrm{a}$ \\
\hline
\end{tabular}

Each value represents the average of three replicates per treatment \pm SE (standard Error). In the same column, significant differences according to LSD at $P \leq 0.05$ levels are indicated by different letters. The germination percentage were measured on 96 hour after sowing.

Table 5. Effect of B. iodinum RS16, M. oryzae CBMB20 inoculation on early growth of maize under different levels of salinity stress.

\begin{tabular}{lccc}
\hline \hline \multirow{2}{*}{ Treatment } & \multicolumn{3}{c}{ Root length $\left(\mathrm{cm} \mathrm{plant}^{-1}\right)$} \\
\cline { 2 - 4 } & $50 \mathrm{mM} \mathrm{NaCl}$ & $100 \mathrm{mM} \mathrm{NaCl}$ & $150 \mathrm{mM} \mathrm{NaCl}$ \\
\hline Non-inoculation & $18.8 \pm 0.6 \mathrm{~b}$ & $13.7 \pm 1.5 \mathrm{~b}$ & $8.1 \pm 1.1 \mathrm{~b}$ \\
B. iodinum RS16 & $19.8 \pm 0.3 \mathrm{~b}$ & $16.2 \pm 0.4 \mathrm{a}$ & $9.0 \pm 0.9 \mathrm{~b}$ \\
M. oryzae CBMB20 & $19.5 \pm 0.3 \mathrm{~b}$ & $15.2 \pm 0.3 \mathrm{ab}$ & $8.5 \pm 0.3 \mathrm{~b}$ \\
Co-inoculation & $21.7 \pm 0.5 \mathrm{a}$ & $16.4 \pm 0.5 \mathrm{a}$ & $10.5 \pm 0.5 \mathrm{a}$ \\
\hline
\end{tabular}

Each value represents the average of three replicates per treatment \pm SE (standard Error). In the same column, significant differences according to LSD at $P \leq 0.05$ levels are indicated by different letters. In the absence of $\mathrm{NaCl}$ and bacterial inoculation root length was $21.7 \pm 1.2 \mathrm{~cm}$.

The root length were measured 7 days after sowing (DAS).

Table 6. Effect of B. iodinum RS16, M. oryzae CBMB20 inoculation on early growth of sorghum-sudangrass hybrid under different levels of salinity stress.

\begin{tabular}{lccc}
\hline \hline \multirow{2}{*}{ Treatment } & \multicolumn{3}{c}{ Root length $\left(\mathrm{cm} \mathrm{plant}{ }^{-1}\right)$} \\
\cline { 2 - 4 } & $50 \mathrm{mM} \mathrm{NaCl}$ & $100 \mathrm{mM} \mathrm{NaCl}$ & $150 \mathrm{mM} \mathrm{NaCl}$ \\
\hline Non-inoculation & $14.7 \pm 0.9 \mathrm{~b}$ & $12.3 \pm 1.2 \mathrm{a}$ & $7.8 \pm 0.9 \mathrm{~b}$ \\
B. iodinum RS16 & $17.6 \pm 1.1 \mathrm{a}$ & $13.4 \pm 1.5 \mathrm{a}$ & $8.8 \pm 0.8 \mathrm{~b}$ \\
M. oryzae CBMB20 & $14.6 \pm 1.5 \mathrm{~b}$ & $13.9 \pm 0.4 \mathrm{a}$ & $11.1 \pm 1.1 \mathrm{a}$ \\
Co-inoculation & $18.7 \pm 1.4 \mathrm{a}$ & $13.9 \pm 1.5 \mathrm{a}$ & $9.9 \pm 0.2 \mathrm{~b}$ \\
\hline
\end{tabular}

Each value represents the average of three replicates per treatment \pm SE (standard Error). In the same column, significant differences according to LSD at $P \leq 0.05$ levels are indicated by different letters. In the absence of $\mathrm{NaCl}$ and bacterial inoculation root length was $17.5 \pm 0.6 \mathrm{~cm}$.

The root length were measured 7 days after sowing (DAS). 
$\mathrm{NaCl}$ and bacterial inoculation treatments $(17.5 \mathrm{~cm})$. Previously, roots have been reported to be less sensitive to salinity than leaves (Rendig and Taylor, 1989). However, in the present study, root length was severely affected with the highest salinity level tested in this study.

\section{Effect of salinity stress and bacterial inoculation on} the maize and sorghum-sudangrass hybrid seedlings root growth under Gnotobiotic pouch assay Inoculation with PGP strains $B$. iodinum RS16 and M. oryzae CBMB20 significantly promoted growth of maize seedling under different $\mathrm{NaCl}$ concentrations. In general, inoculation of PGPR resulted in early seedling growth and development (Egamberdiyeva, 2009) but normal plant growth will be reduced by increasing salinity. However, inoculation of PGPR was effective in the presence of $120 \mathrm{mM}$ of $\mathrm{NaCl}$ (Nadeem et al. 2006). In the present work single inoculation of $B$. iodinum $\mathrm{RS} 16$ or $M$. oryzae $\mathrm{CBMB} 20$ and their co-inoculation increased growth of maize and sorghum-sudangrass hybrid seedlings compared to non-inoculated plants at different levels of salinity stress (Table 5 and Table 6). In particular, co-inoculation significantly increased root length of maize seedling by $22.9 \%$ as compared to non-inoculated plants at $150 \mathrm{mM} \mathrm{NaCl}$ concentration (Table 5) and inoculation of $M$. oryzae CBMB20 significantly increased root length of sorghum-sudangrass hybrid seedling by $29.7 \%$ as compared to non-inoculated control at 150 $\mathrm{mM}$ concentration (Table 6). It was observed that inoculation with these PGP strains significantly improved root length at all salinity levels tested. Inoculating ACC-deaminase containing rhizobacterial strains reduced the stress ethylene level and increased shoot and root growth significantly under high $\mathrm{NaCl}(200 \mathrm{mM})$ conditions (Mayak et al. 2004). This kind of alleviation of salt stress by an ACC-deaminase possessing bacterial strain was demonstrated under green house and field conditions and in another study, mechanism was conclusively proved using ACC-deaminase minus mutants in canola plants (Saravananakumar and Samiyappan, 2006; Cheng et al. 2007).

\section{Conclusion}

The results of this study proved that inoculation of seeds with PGPR strains containing ACC-deaminase
(B. iodinum RS16 and M. oryzae CBMB20) promotes germination and root growth of maize and sorghumsudangrass hybrid grown under high $\mathrm{NaCl}$ levels. ACCdeaminase containing bacteria are already known to promote plants growth under salinity stress condition. The strains used in this study have enhanced tolerance of maize and sorghum-sudangrass hybrid under high salinity level, which eventually lead to better germination, root and shoot growth compared to non-inoculated plants. Further work is needed to explore other synergistic PGP mechanisms associated with crop establishment under salinity stress condition. Thus this study could pave way for evaluation of PGP activities of $B$. iodinum RS16 and M. oryzae CBMB20 under reclaimed soil conditions.

\section{Acknowledgements}

This work was supported by Korea Institute of Planning \& Evaluation for Technology in Food, Agriculture, Forestry and Fisheries (iPET), Republic of Korea.

\section{References}

Ahmad, F., I. Ahmad, and M.S. Khan. 2006. Screening of Free-living Rhizospheric Bacteria for their Multiple Plant Growth Promoting activities. Microb. Res. 36:1-9.

Almodares, A., M.R. Hadi, and B. Dosti. 2007. Effects of salt stress on Germination Percentage and Seedling Growth in Sweet Sorghum Cultivars. J. Biological Sci. 7(8):1492-1495.

Bacilio, M., H. Rodriguez, and M. Moreno. 2004. Mitigation of Salt stress in Wheat seedlings by gfp-tagged Azospirillum lipoferum. Biol Fertil soils. 40:188-193.

Belimov, A.A., N. Hontzeas, and V.I. Safronova. 2005. Cadmium-tolerant Plant Growth Promoting Bacteria Associated with the Roots of Indian mustard. Soil Biol Biochem. 37: 241-250

Bharathi, R., R. Vivekananthan, S. Harish, A. Ramanathan, and R. Samiyappan. 2004. Rhizobacteria-based Bio-formulations for the Management of Fruit rot infection in chillies. Crop Protec. 23:835-843.

Blanco, F.F., M.V. Folegatti, H.R. Gheyi, and P.D. Fernandes. 2007. Emergence and Growth of Corn and Soybean Under Saline Stress. Sci. Agric (Piracicaba, Braz.). 64(5):451-459.

Blum, A. 1985. Breeding for Crop Varieties for Stress Environments Crit. Rev. Plant Sci. 2:199-238.

Bray, E.A., J. Bailey-Serres and E. Weretilnyk. 2000. Responses to abiotic stress. Biochemistry and Molecular Biology of Plants. American Society of Plant Physiology. Rockville. 
1158-1203.

Bybordi, A., and S.J. Tabatabaei. 2009. Effect of Salinity Stress on Germination and Seedling Properties in Canola Cultivars (Brassica napus L). Notulae Botanicae Horti Agrobotanici Cluj-Napoca. 37(1):71-76.

Cattelan, A.J., P.G. Hartel, and J.J. Fuhrmann. 1999. Screening for Plant Growth Promoting Rhizobacteria to Promote Early soybean growth. Soil Sci. Soc. Am. J. 63:1670-1680.

Cuartero, J., M.C. Bolarin, M.J. Asins, and V. Moreno. 2006. Increasing Salt Tolerance in the Tomato. J. Exp. Bot. 57(5): 1045-1058.

Egamberdiyeva, D. 2007. The Effect of Plant Growth Promoting Bacteria on Growth and Nutrient Uptake of Maize in Two Different Soils. Appl. Soil. Eco. 36:184-189.

Egamberdiyeva, D. 2009. Alleviation of Salt Stress by Plant Growth Regulators and IAA Producing Bacteria in wheat. Acta Physiol Plant. 31:861-864.

Ghosh, S., J.N. Penterman, and R.D. Little. 2003. Three Newly Isolated Plant Growth Promoting Bacilli Facilitate The Seedling Growth Of Canola, Brassica Campestris. Plant Physiol Biochem. 41:277-281.

Gill, P.K., A.D. Sharma, P. Singh, and S.S. Bhullar. 2002. Osmotic Stres-Incuded Changes in Germination, Growth and Soluble Sugar Changes of Sorghum bicolor (L.) Seeds. Bulg. J. Plant Physiol. 28:12-25.

Glick, B.R., C. Liu, and S. Ghosh. 1997. Early Development of Canola Seedlings in the Presence of the Plant Growth Promoting Rhizobacterium Pseudomonas putida GR12-2, Soil Biol Biochem. 29:1233-1239.

Glick, B.R., D.M. Penrose, and J. Li. 1998. A Model for the Lowering of Plant Ethylene Concentrations by Plant Growth Promoting Bacteria, J Theor Biol. 190:63-68.

Grichko, V.P., and B.R. Glick. 2001. Amelioration of Flooding Stress by ACC deaminase-containing Plant Growth Promoting Bacteria. Plant Physiol Biochem. 39:11-17.

Jackson, M.B. 1997. Hormones from Roots as Signal for the Shoots of Stressed Plants. Trends Plant Sci. 2:22-28 64.

Jeun, Y.C., K.S. Park, C.H. Kim, W.D. Fowler and J.W. Kloepper. 2004. Cytological Observations of Cucumber Plants During Induced Resistance Elicited by Rhizobacteria. Biol. Contorl. 29:34-42.

Khan, M.A., and I.A. Ungar. 1985. The Role of Hormones in Regulating the Germination of Polymorphic Seeds and Early Seedling Growth of Atriplex triangularis Willd. under saline conditions. Physiol. Plant. 63:109-113.

Kokelis-Burelle, N., J.W. Kloepper and M.S. Reddy. 2006. Plant Growth Promoting Rhizobacteria as Transplant Amendments and their Effects on Indigenous Rhizosphere Microorganisms. App. Soil Ecol. 31:91-100.

Madhaiyan, M., B.Y. Kim, S. Poonguzhali, S.W. Kwon, M.H. Song, J.H. Ryu, S.J. Go, B.S. Koo, and T.M. Sa. 2007. Methylobacterium oryzae spp. nov., a Novel Aerobic, Pinkpigmented, Facultatively Methylothropic, 1-aminocyclo-propan1-carboxylate Deaminase Producing Bacterium Isolated from Rice. Int. J. Syst, Evol. Microbiol. 57:326-331.

Mayak, S., T. Tirosh, and B.R. Glick. 2004. Plant Growth
Pomoting Bacteria Confer Resistance in Tomato Plants to Salt Stress. Plant Physiol Biochem. 42:565-572.

Mohammad, M.R., M.A., Shibli and L. Nimri. 1998. Tomato Root and Shoot Responses to Salt Stress Under Different levels of Phosphorus Nutrition. Journal of plant nutrition. 21(8):1667-1680.

Munns, R. 2002. Comparative Physiology of Salt and Water Stress. Plant Cell Environ. 25:239-250.

Nadeem, S.M., A. Zahir, M. Zahir, M. Naveed, Arshad, and S.M. Shahzad. 2006. Variation in Growth and Ion uptake of Maize due to Inoculation with Plant Growth Promoting Rhizobacteria under Salt Stress. Soil \& Environ. 25(2):78-84.

Nelson, L.M. 2004. Plant growth promoting rhizobacteria (PGPR): Prospects for New Inoculants. Online. Crop Management doi: 10.1094 / CM-2004- 0301-05-RV.

Neumann, P.M. 1995. Inhibition of Root Growth by Salinity Stress. In: Structure and Function of Roots. Baluska F, Ciamporova M, Gasporikova O, Barlow PW (Eds.). Kluwer Academic Publishers, Netherlands. 299-304.

Rendig, V.V., and H.M. Taylor. 1989. Principles of Soil-plant Interrelationships. McGraw- Hill, New York, NY.

Salantur, A., A. Ozturk, and S. Akten. 2006. Growth and Yield Response of Spring Wheat (Triticum aestivum L.) to Inoculation with Rhizobacteria. Plant. Soil. Environ. 52(3): 111-118.

Saritha, V., and M.N.V. Kuriakose-Prasad. 2007. Cadmium Stress Affects seed Germination and Seedling growth in Sorghum bicolor (L.) Moench by Changing the Activities of Hydrolyzing Enzymes. Plant Growth Regul. 54:43-156.

Shaharoona, B., M. Arshad, and Z.A. Zahir. 2006. Effect of Plant Growth Promoting Rhizobacteria Containing ACC-deaminase on Maize (Zea mays L.) Growth under Axenic Conditions and on Nodulation in Mung bean (Vigna radiata L.). Lett Appl Microbiol, 42:155-159.

Siddikee, Md.A., P.S. Chauhan, T.M. Sa. 2011a. Regulation of Ethylene Biosynthesis Under Salt Stress in Red Pepper (Capsicum annuum L.) by 1-Aminocyclopropane-1-Carboxylic Acid (ACC) Deaminase producing Halotolerant Bacteria. J Plant Growth Regul. DOI 10.1007/s00344-011-9236-6.

Siddikee, Md.A., R. Bernard, B.R. Glick, P.S. Chauhan, W.J. Yim, and T.M. Sa. 2011b. Enhancement of Growth and Salt Tolerance of Red pepper seedlings (Capsicum annuum L.) by Egulating Stress Ethylene Synthesis with Halotolerant Bacteria Containing 1-aminocyclo- propane-1-carboxylic acid deaminase activity. Plant Physiology and Biochemistry, 49:427-434.

Simon, E.W. 1984. Early Events in Germination. In: Murray DR, ed. Seed physiology. Australia: Academic Press.

Taffouo, V.D., M. Kenne, O. Wamba-Fotsop, M.L. Sameza, M. Ndomou and A. Amougou. 2006. Salinity Effects on Growth, Ionic Distribution and Water Content in Salt-tolerant Species Gossypium hirsutum (Malvaceae). J. Cam. Acad. Sci. 6: 167-174.

Uhvits, R. 1946. Effect of Osmotic Pressure on Water Absorption and Germination of Alfalfa seeds. American Journal of Botany. 33:278-284.

Werner, J.E, and R.R. Finkelstein. 1995. Arabidopsis Mutants 
with Reduced Response to $\mathrm{NaCl}$ and Osmotic Stress. Physiologia Plantarum. 93:659-666.

Wu S.C., Z.H. Cao, Z.G. Li, K.C. Cheung, and M.H. Wong. 2005. Effects of Biofertilizer Containing $\mathrm{N}$-fixer, $\mathrm{P}$ and $\mathrm{K}$ solubilizers and AM fungi on Maize Growth: a greenhouse trial. Geoderma. 125:155-166.
Zadeh, H.M. and M.B. Naeni. 2007. Effects of Salinity Stress on the Morphology and Yield of Two Cultivars of Canola (Brassica napus L.). J. Agron. 6:409-414.

Zholkevich, V.N. and T.N. Pustovoytova. 1993. The Role of Cucumis sativum L Leaves and Content of Phytohormones under Soil Drought. Russ. J. Plant Physiol. 40:676-680. 